\title{
Rice Landrace Conservation Practice through Collective Memory and Toraja Foodways
}

\section{Ikma Citra Ranteallo ${ }^{1 *}$ (D), Meredian Alam 2 (D), Azwar Hadi Nasution ${ }^{3}$ (D), Lala M. Kolopaking 1* (D), Djuara P. Lubis ${ }^{1}$ (D), Ervizal A. M. Zuhud ${ }^{4}$ (D), and Imanuella R. Andilolo 5 (D)}

${ }^{1}$ Department of Communication Science and Community Development, Faculty of Human Ecology, IPB University, 16680, Bogor, West Java, Indonesia ${ }^{2}$ Department of Sociology and Anthropology, Faculty of Arts and Social Science, Universiti Brunei Darussalam, Jalan Tungku Link, BE 1410, Brunei Darussalam

${ }^{3}$ Association of Indonesian Seed Bank and Farmers Agricultural Technology (AB2TI), 16155, Bogor, West Java, Indonesia

${ }^{4}$ Department of Forest Resources Conservation and Ecotourism, Faculty of Forestry, IPB University, 16680, Bogor, West Java, Indonesia

${ }^{5}$ Department of Management, Faculty of Economics and Business,

Universitas Mataram, 83125, Mataram, West Nusa Tenggara, Indonesia

*Corresponding Author: lalako@apps.ipb.ac.id; ikma_citra@unud.ac.id

\section{ARTICLE INFO}

\section{Publication Info: \\ Research Article}

How to cite:

Ranteallo, I. C., Alam, M., Nasution, A. H., Kolopaking, L. M., Lubis, D. P., Zuhud, E. A. M., Andilolo, I. R. (2020). Rice Landrace Conservation Practice through Collective Memory and Toraja Foodways. Society, 8(2), 794-817.

DOI: $10.33019 /$ society.v8i2.211

Copyright $\odot$ 2020. Owned by Author(s), published by Society

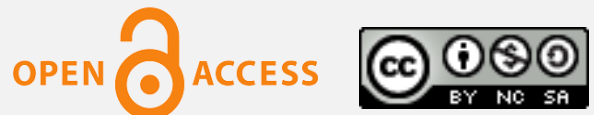

This is an open-access article.

\begin{abstract}
Many studies on rice landrace (Oryza sativa sbsp. indica) have been conducted by biodiversity, ethnobotany, and agroecology disciplines. The importance of rice landraces as genetic resources and the basics of human civilizations. Conservation landraces in Tumbang Datu and Pongbembe nowadays are affected by the following socio-cultural constraints: a) decline numbers of local varieties after the regional governmentimposed funding to local communities to substitute new-high yield varieties, b) rice rites and landrace conservation are on the brink of extinction. This research explores daily behaviors that contribute to rice landrace conservations through the sociological approach of collective memory and symbolic interaction. Today's generations use new meanings and symbols of rice derived from collective memories and virtues. Various interviewees practice mnemonic devices (what, why, who, where, when, and how) that reflect foodways. According to Blumer, social structures are networks of interdependence among actors that place conditions on their actions. In these networks, people act and produce symbols and meanings of rice to interpret their situations and to have their own set in a localized process of social interpretation. Moreover, the Toraja
\end{abstract}

Copyright (C 2020. Owned by Author(s), published by Society. This is an open-access article under the CC-BY-NC-SA license. 


\section{License: Attribution- NonCommercial-ShareAlike (CC BY-NC-SA)}

Received: July 16, 2020;

Accepted: October 26, 2020;

Published: December 31, 2020; language is used as a bridge in communicating the past, present, and future to strengthening collective identity. This research uses a qualitative method to explore rice landrace conservation using open-ended questions, in-depth interviews, and Focus Group Discussions. A free-listing method was followed to gather interviewees' collective memories of rice landraces. Findings show that a combination of methods, tradition-based conservation, and current scientifictechnology-based conservation become a practice for promoting, educating, and stimulating the public and researchers to engage in landraces conservation. These findings suggest that the socio-cultural ecosystem and Blumer's social network support new networks to deliver science in agricultural innovation policy. The results showed that collective memories and foodways create ways that would benefit rice landrace conservation the most.

$\begin{array}{ll}\text { Keywords: } & \text { Collective Memory; Collective Identity; } \\ & \text { Conservation; Foodways; Rice Landrace; } \\ & \text { Symbolic Interactionism }\end{array}$

\section{Introduction}

Rice landrace conservation as a part of everyday life has been relatively neglected. Hongsong \& Yunyue (2017) stated the decreasing number of rice landrace was due to government aid for new varieties, a small number of rice rites and cultural performances related to agriculture in the community, and higher cost of post-production activities. Nevertheless, rice landrace cultivation, daily consumption, and rice ritual are the main contributions of individuals and communities to conservation. Hence, rice landrace conservation is urgent to undertake for supplying staple food in the future (Kumbhar et al., 2015).

Foodways are related to the behaviors and beliefs of production, distribution, and food consumption (Counihan, 1999). In this contribution, collective memory on meanings and symbols of rice is supporting by the combination methods of conservation: tradition-based (non-standard method) and current scientific technology (scientific technology introduced by agricultural agency and agricultural extension). Interviewees are cultivating rice landraces and practicing foodways by restoring collective memory. Interviewees named simple morphology of the landraces (Table 2), shared what to do in planting and harvesting seasons, how to cultivate, store, cook, consume, sell, and communicate the knowledge of rice, the essential values of cultural heritage, collective identity, and circulating the seeds, also by who and where the ritual rice is organized (Figure 1).

Social sciences are increasingly paying attention to social life and institutions for protecting natural resources. Best Available Social Science (BASS) has been concerned with sustainability, conservation biodiversity, social science application in decision-making, and natural resource management (Charnley et al., 2017). Coleman et al. (2019) found two themes of one hundred priority research questions for biodiversity conservation in Southeast Asia: 1) documenting biodiversity loss and its causes, and 2) social interventions that would effectively change peoples' minds about conservation. Daily behaviors are conservation strategies as mnemonic 
devices (Figure 1) to retain and preserve rice landrace' knowledge. Cultivating rice landrace, daily consumption, and rice rites are individuals' or communities' contributions for conservation. Landrace varieties are produced and kept primarily for ritualistic purposes each year, as Baduy people practice in West Java (Murphy, 2017).

According to Juhriah et al. (2014), Tana Toraja is one of rice-producing regions in Indonesia, also has rice landrace varieties (rice known as pare in Toraja language): Pare Lalodo, Pare Rogon, Pare Lea, Pare Kobo, Pare Ra'rari, Pare Ambo,' Pare Tallang, Pare Bau,' Pare Birang, and Pare Bumbungan. In this article, we first briefly elaborate earlier domestication and consumption of rice landrace. This is followed by the explanations on collective memory as the foundations for conserving rice landraces cultural practices and its challenges, and drawing contributions of symbolic interactionism approach (Macionis, 2018) to consider how networks of collective memory and mnnemonic devices bridge the past and the present. We then proceed to presentation of the findings, and the research methodology to address gaps in conservation biodiversity literatures: qualitative exploratory method to gather how the interviewees employ collective memory to take various parts in conserving rice landrace. Based on observation, this research argues communities in Tumbang Datu and Pongbembe, Tana Toraja, South Sulawesi cultivate landraces according to new negotiated meanings and rice symbols. Finally, we summarize our findings.

\section{Literature Review}

\subsection{Rice Landrace}

Iskandar \& Ellen (1999) stated rice landrace is a local category for grouping cultivated rice plants according to common characteristics reflected in specific vernacular names. Landraces represent locally distinguished germplasm developed by farmers, in contrast to 'varieties,' usually the institutional breeding products. Rice was the result of domestication from wild plants into cultivated plants. Landrace relates to the origin of the domestication area of plants with a high varied environment (Brush, 1991). However, the first rice domestication of rice is still a debate. The traditional phylogenetic method that produces molecular data more unfolds that the varieties of Indica and Japonica are the two main rice varieties in the world (Molina et al., 2011; Wang et al., 2016).

Based on historical records (Van Driem, 2012), director of the botanical garden in Geneva, Alphonse-Louis-Pierre Pyrame de Candolle, in 1883, stated that rice cultivated first in China then introduced to India. However, Nikolaï Ivanovič Vavilov, in 1926, denied it and pointed out that rice in Asia originated from India. Indonesians who migrated are recognized rice before they arrived in the Malay Archipelago. Some scholars revealed that the word "Javanese" comes from "Djawa" or "Djawa Dwipa" (rice island in Sanskrit) (van der Kroef, 1952). Rice is a staple food for most people in Southeast Asia. People consume rice daily in different traditional menus with authenticity is still preserved, and highly values rice as the primary ingredient for making the local cuisines' main menus (Ajwang'Ondiek et al., 2016).

\subsection{Cultural Practices of Rice Conservation and Its Challenges}

Collective memory, which includes the basics of rice landrace cultivation and socioreligious values, is one of the foundations for rice landrace conservation. These memories are treated and adapted to the present condition, so that local varieties of rice as a genetic resource are kept, although some of these varieties are rare or potentially extinct (Wang et al., 2016). According to Law No. 5/1990 concerning on Conservation of Natural Resources and Its Ecosystems, it can be carried out through three activities: 1) protection of life support systems; 
2) preservation of the diversity of plant and animal species and its ecosystems; and 3) sustainable use of natural resources and its ecosystems. Conservation has been carried out to keep livestock germplasm (Soini et al., 2012) and plants (Wang et al., 2016), protected areas of land and sea (Álvarez-Romero et al., 2018), also protect the conservationists and their knowledge (Oguamanam, 2004).

Historically, rice was produced for maintaining social, cultural, and spiritual purposes. As implemented in the Philippines, the Ifugao rice terrace is an heirloom to support community needs for staple food consumption (Glover \& Stone, 2018). Their awareness of modernization is preserved as a pro-people movement to enable sustainability in extended period (Arangote, 2018). However, the tension between traditionalism being inherent in community life and modern development in agriculture is unavoidable. Post green revolution agriculture system, in which mass production is emphasized in the implementation principle, can shift local varieties (Tilliger et al., 2015). Preserved cultural practices by the community for centuries have been replaced by new varieties resulting from genetic modification. The establishment of private companies is expansive due to the demands of massive rice consumption in various countries. The companies run their branches and subsidiaries with a different focus, ranging from slip research, genetic innovation, seed planting, fertilization, and harvest management to distributing these varieties. Weakening local institutions are the cause of the failure to strengthen and develop these landraces varieties.

The failure of the green revolution agriculture system has altered the structure of people's knowledge and farming techniques. Green Revolution has appropriated policy, high-input seeds that keep away locally adapted landraces, and the attitudes and practices. It is the case for Golden Rice in the Philippines. This rice, which increases its value as a means for community relations, is also a significant barrier in reaching farmer fields because it proves difficult to breed into well-grown varieties, especially in the rural Philippines (Gopi \& Manjula, 2018). Therefore, rural communities that act as the direct implementer at the grassroots level gained no profits. Therefore, local varieties' social sustainability in the coming years also depends on strength at the villagers' level. Another element that can shift the stability of rice landraces farming is migration and commercialization tradition through tourism.

\subsection{Contributions of Symbolic Interactionism in Conservation: Collective Memory, Mnemonic Devices, and the Networks}

Collective memory plays an important role in rice landrace conservation. Individual-level memory updating phenomena and social network structure are two fundamental factors that contribute to the emergence of collective memories (Coman et al., 2016). Collective memory is a living concept linked to the behaviors and responses of individuals that generate meanings. Community members often have experimental commonalities and create collective memories around these observed commonalities. This article explores the interviewees' daily behaviors on cultivating landraces, rice rituals, expressing the delicious flavor of rice, and other landraces landmarks that help us understand collective memory. Collective memories, in turn, can be passed down from one generation to the next and can eventually be the cultural heirloom produced by the community (Cuc et al., 2007, as cited in Hirst, 2020). The recognition that history results from the social entity, even while it was based on subjective constructs, proves that social memory studies fit rigorous symbolic interactionism theoretical approaches (Fine \& Beim, 2007).

Rice is the symbol of Toraja's prosperity (Zerner, 1985). Nooy-Palm (1979) sees that: 
"...There are countless traditions concerning its origins..., but they fall into two categories: the first contains the myths in which rice is created in the upper world and afterward brought to the earth, and the second those which tell how rice was created on earth."

Collective memory is the outcome processes affecting, respectively, the information to which individuals have access (DiMaggio, 1997). The past's continuous communication profoundly alters what people remember as they converse and remember after the conversation. Mnemonic devices are strategies for enhancing memory (Figure 1). Mnemonic was derived from the name of the goddess of memory, Mnemosyne, in Greek mythology (Laing, 2010). Mnemonic imagination bridges the past, present, and future, and supplies of thinking about the relationship between understanding the past, actions in the present, and future ambitions (Keightley \& Pickering, 2012). Aluk pare (the ritual cycle associated with cultivates rice) as a mnemonic device and strategy to recall collective memories related to rice in the past constituted a distinct sphere of ceremonial life. Zerner (1985) has added that:

"...These affirmative ceremonies, associated with the rising sun and the growth of plants, were conducted by ritual specialists called to minaa, 'The Wise Ones' and indo' padang, 'Mothers of the Land,' with a prodigious knowledge of myth, custom, and ceremonial speech. These masters of ceremonies inaugurate crucial phases in the calendar of cultivation."

"...If the community of cultivators remembers the ritual performances, then 'all ancestors' are awakened. In a state of heightened attention, the spirits, 'guardians of the three stalks of rice' [pare tallu bulinna, ke'te' tallu etengna: another term for rice; symbol of prosperity and life], ensure the fruitful cultivation of rice."

Network analysis in symbolic interactionism is reflected in daily behaviors in Tumbang Datu and Pongbembe. As various interviewees' backgrounds, the expressions on symbols and meanings of rice reflected by how, when, and which essential varieties to cultivate; or the symbols of motifs on wooden-carving granary. Every stage in this cycle brings people together. Blumer (1969), as cited in Ritzer (2011) puts it:

“...A network or an institution does not function automatically because of some inner dynamics or system requirements; it functions because people at different points do something, and what they do is a result of how they define the situation in which they are called on to act."

Through social interactions, human beings become aware of what others are doing or about what they are willing to do (Aldiabat \& Navenec, 2011). Aluk pare is a communal ritual in rice landrace cultivation (Kruyt, 1938). Appelrouth \& Edles (2007) stated:

"...It is necessary to recognize that the sets of meanings that lead participants to act as they do at their stationed points in the network have their setting in a localized process of social interaction and that these meanings are formed, sustained, weakened, strengthened, or transformed, as the case may be, through a socially defining process." 
This study conducts a symbolic interaction approach to explore rice landrace conservation and collective memories of past foodways. In exploring how foodways relate to conservation rice landrace, this research uses a symbolic interaction approach to revisiting collective memory and foodways in the past. As the symbol of prosperity, rice as tananan (plant) in aluk tananan (plant ritual) also can be found in singgi' (praise chant declaimed by the officiants during the big bua' ceremony) and tallu lolona (lolo tau (humans), lolo tananan (rice, refers to plants), and lolo patuan (buffalo, refers to livestock) (Veen, 1979). Nooy-Palm (1979) puts it:

"...The most important category among the West-oriented rituals is the aluk to mate, rituals for the dead (mate). The aluk rampe matallo, those of the East, rituals for the living, promote the welfare of man, animals and crops."

The agricultural cycle in Toraja culture is a set of rituals and social events bound together emotionally. Symbolic interactionism is rooted in "how people do things together" (Becker, 1986, as cited in Plummer, 2000). A social network is a concept interactionists might use to link individual behavior to the more extensive social system. A network is conceived as a set of relationships that people fill with meaning and use for personal or collective purposes (Fine \& Kleinman, 1983). This approach reveals how transmitting foodways and collective memory on rice landrace is a strategy for conservation.

\section{Research Methodology}

This research was conducted in two villages, Tumbang Datu in Sanggalla' Utara Subdistrict and Pongbembe in Simbuang Subdistrict, Tana Toraja Regency of South Sulawesi Province, Indonesia. These villages have different characters for conserving rice landraces. Simbuang encompasses $194,82 \mathrm{~km}^{2}$ is included of six villages with a population of 6,427 according to the 2018 census. A total of 925 population are working on agricultural sector. Geography position of Pongbembe at $119^{\circ} 31^{\prime \prime} 47.91 \mathrm{E}$ and $3^{\circ} 11^{\prime \prime} 6.76^{\prime \prime} \mathrm{S}$, and altitude range between $1300 \mathrm{~m}$ and 2000 $\mathrm{m}$ above sea level (asl). We need to travel over $70 \mathrm{~km}$ from Makale, capital of regency. Sangalla' Utara encompasses $27,96 \mathrm{~km}^{2}$ is comprised of six villages with a population of 7,630 according to the 2018 census (BPS). Geography position of Tumbang Datu at 119 $54^{\prime \prime 25.56 " ~ E ~ a n d ~}$ $3^{\circ} 3^{\prime \prime} 1.76^{\prime \prime} \mathrm{S}$, altitude range between $750 \mathrm{~m}$ and 1,100 $\mathrm{m}$ asl, and $14 \mathrm{~km}$ from Makale. There is a temple and 2,605 adherents of Aluk To Dolo in Simbuang, and 51 adherents of Aluk To Dolo in Sangalla' Utara Subdistrict. Simbuang has 155 hectares (ha) of irrigation wetlands and 283 ha of non-irrigation wetlands. Sangalla' Utara has 90 ha of irrigation wetlands and 548 ha of nonirrigation wetlands. The planted area of wetland paddy 1,418 ha in Simbuang, whereas Sangalla' Utara has 2,050 ha. Harvested area of wetland paddy in Simbuang about 1,454 ha, less than Sangalla' Utara with 1,754 ha (Badan Pusat Statistik Kabupaten Tana Toraja, 2018a; 2018b).

We employed descriptive analyses, open-ended questions with in-depth interviews, and qualitative technique of free listing to collect and code interviewees' collective memory of cultivating and consuming of rice landraces, landrace diversities, vernacular naming, and descriptions of socio-cultural values. Data collection was carried out from December 2018 to May 2019. This study used symbolic interactionism in sociology, ethnobotany, and communication studies as a basic framework. Ethnobotany finds and describes the social practices in which plants are used, in different use and knowledge, and memories of practices. Ethnobotany is the study of knowledge and use of plants in the past and present, including technological manipulation, classification, agricultural systems, magico-religious concepts, conservation techniques, and general economic and sociological importance plants in primitive 
or pre-literate societies (Schultes, 1994). In this study, communication dealt with ethnobotanical knowledge passed down the generations using Toraja language as a mnemonic device.

This transdisciplinary approach aims to contribute to conserving rice landrace varieties. While definition of transdisciplinary is still debated, this approach raises critical issues in science: 1) the issue's complexity that is grasped, 2) the diverse perspectives on the issue that are considered, 3) abstract and case-specific knowledge that is linked, and 4) common-good oriented descriptive, normative, and practical knowledge to address the issue that is developed (Pohl, 2011). This approach manages to challenge some significant obstacles confronted by a dominant intellectual paradigm that conceptually separates culture and nature, rather than considering human-environmental interaction as a dynamic, interpenetrative engagement (Strang, 2007). This qualitative research uses Social Definition Paradigm and Symbolic Interactionism Theory. Symbolic interactionism aims to decipher the meaning of the rice symbols, found in the symbol of the granary (alang) and family houses (banua tongkonan), and rice rites (aluk pare). Symbols are something meaningful and represent something else, for example, signs and cues (Kendall, 2010). The symbol serves to give meaning to the communication in direct interaction or interaction with intermediary media.

\section{Results and Discussion}

Focus Group Discussion and with all interviewees (Table 1) were conducted in Bahasa and Toraja languages to gain more insights into everyday behaviors of collective memory and conservation rice landrace. Since every interviewee is contributing to any form of conserving rice landrace, the selection of interviewees was arranged purposively with various ages, gender, and occupations.

Table 1. Demographic of Interviewees

\begin{tabular}{|c|c|c|c|c|}
\hline ID & Age & Gender & Occupation & Location \\
\hline F1 & 50 & Female & Weaver, Farmer & Pongbembe \\
\hline M1 & 36 & Male & $\begin{array}{c}\text { Village Guidance Officer } \\
\text { (noncommissioned law enforcement } \\
\text { officer) }\end{array}$ & $\begin{array}{c}\text { Tana Toraja } \\
\text { M2 }\end{array}$ \\
\hline F2 & 51 & Male & $\begin{array}{c}\text { One of the leaders of Aluk To Dolo } \\
\text { (ancestor's religion), } \\
\text { Handicraft Man, Farmer }\end{array}$ & Tumbang Datu \\
\hline M3 & 76 & Male & One of the leaders of Aluk To Dolo & Tumbang Datu \\
\hline F3 & 67 & Female & $\begin{array}{c}\text { One of the leaders of Aluk To Dolo, } \\
\text { Farmer }\end{array}$ & Tumbang Datu \\
\hline F4 & 70 & Female & Stay-at-home spouse & Pongbembe \\
\hline F5 & 13 & Female & Junior High School Student & Pongbembe \\
\hline M4 & 50 & Male & Retired & Simbuang \\
\hline M5 & 56 & Male & State Civil Apparatus & Simbuang \\
\hline F6 & 13 & Female & Junior High School Student & Tumbang Datu \\
\hline F7 & 14 & Female & Junior High School Student & Tumbang Datu \\
\hline F8 & 14 & Female & Junior High School Student & Tumbang Datu \\
\hline
\end{tabular}

Copyright (C) 2020. Owned by Author(s), published by Society. This is an open-access article under the CC-BY-NC-SA license. https://doi.org/10.33019/society.v8i2.211

800 


\begin{tabular}{|c|c|c|c|c|}
\hline ID & Age & Gender & Occupation & Location \\
\hline M9 & 17 & Male & Junior High School Student & Tumbang Datu \\
\hline M10 & 36 & Male & Extension Agent & Simbuang \\
\hline F9 & 50 & Female & Farmer, Weaver & Simbuang \\
\hline M11 & 37 & Male & State Civil Apparatus & Tumbang Datu \\
\hline F10 & 45 & Female & Extension Agent & Tumbang Datu \\
\hline
\end{tabular}

Most households in Tumbang Datu are storing dried grains in alang (granary). Wooden granary range in size from $2 \mathrm{~m}$ wide and $4 \mathrm{~m}$ long, with about 96 sacks of grains $(48,000 \mathrm{~kg})$. The grains rice landraces can be loaded for 5 tons into a wooden granary with $180 \mathrm{~m}$ wide and 4 $\mathrm{m}$ long. Most households in Pongbembe were storing dried grains in the granary called batutu (a big wooden box inside the house). Communities are cultivating rice landraces for rituals every year. In earlier times, the more granaries were in front of the house, the richer the owner, and the more they respected by the community. Several granaries meant that the owner has a large, harvested rice area. Recently, the upper structure of alang to store rice bundles, and the bottom of the rice storing as the seat place for the honored guests during rituals (Budiman, 2008).

Rice plays an essential role in the Toraja socio-cultural life (Crystal, 1989). The community upholds rice planting and harvesting rituals, called Aluk Pare (Koubi, 1975; Volkman, 1984; Zerner, 1985; Auersbach, 2018). The rice rites include over forty special tributes. It deals with everything from the purification of the agricultural tools and seeds, the timing of planting and harvesting, rice bundling, and storage order in the granary (Nooy-Palm, 1986, as cited in Tsintjilonis, 2000). The Toraja were exposed to modern history in the 19th century due to its famous Arabica coffee and its slave trade. The internal plotting and rivalries among neighboring kingdoms brought the intervention of the Dutch colonial "pacification" troops in the first decade of the last century, followed by the Christian missions (Ngelow, 2004).

In this research, interviewees use mnemonic devices (tools or ways of remembering) to conserve rice landraces (Figure 1). Network analysis's core concern understands how social structures ease and compel opportunities, behaviors, and cognitions (Salvini, 2010). 'What,' 'when,' 'how,' 'why,' 'where,' and 'who' are the mnemonic devices using by interviewees to preserve socio-cultural values rice landraces. Each item elaborates as follows (Figure 1). 


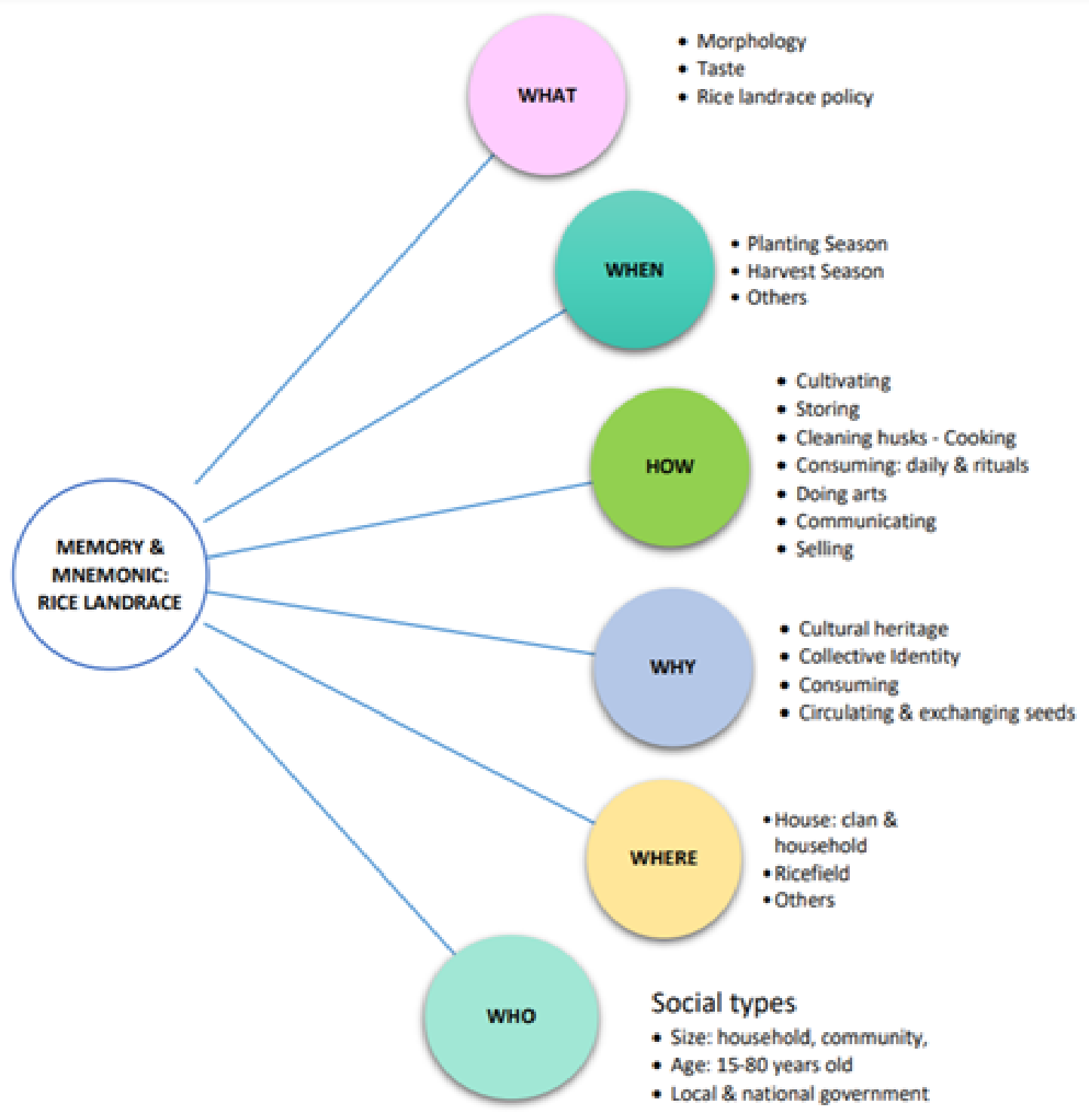

Figure 1. Mnemonic Devices for Conserving Rice Landraces

As shown in Figure 1, seed social network (Poudel et al., 2015; Ohmer et al., 2009) aims to support and cultivate the diverse landrace varieties. Conversations can promote mnemonic convergence between pairs who have directly spoken to one another and occur between pairs connected by a path through their social network (Yamashiro \& Hirst, 2014). In these networks, people act and produce symbols and meanings rice to interpret their situations and have their setting in a localized process of social interpretation. Next, the Toraja language is used to bridge and communicate the past, present, and future and strengthen collective identity. The results showed that collective memories and foodways create ways that would benefit landrace conservation performance the most. Meanwhile, tradition-based conservation and current scientific-technology-based conservation are employing to preserve collective memory and foodways.

\subsection{What: Simple Morphological Analysis, the Flavor of Rice, and Rice-Related Policies}

Morphology comes from the word 'morphe,' in ancient Greek, which means shape or pattern. Morphology, in general, means "discipline of form or pattern," the shape and arrangement of an object's parts, and how this arrangement "adjusts" to achieve wholeness. The "object" in question can be a physical object (e.g., an organism, geography, or ecology), a

Copyright (C) 2020. Owned by Author(s), published by Society. This is an open-access article under the CC-BY-NC-SA license. https://doi.org/10.33019/society.v8i2.211 
social object (an organization or other social system), or a mental object (e.g., a linguistic form, concept, or system of ideas). J. W. von Goethe (1749-1832) first coined morphology as a scientific method that defined in "comparative morphology" in botany (Ritchey, 2011). In this article, simple morphological analysis refers to the description of rice landrace characters: awn color, awn length, rice color, grain color, the shape of grain, and glutinous.

"...This is Pare Boang Kamiri, well known as Pare Pa'barani (more robust rice and pest and disease resistant rice). This variety is the most consumed daily. The tastiest rice is Pare Baine" (Interview, F1, Age 50, Pongbembe).

Symbolic interactionism affirms that individuals derive meaning from memories and keep that knowledge or form new negotiated meanings (Panicker et al., 2020). There are landraces that available in these two villages as follow:

Table 2. Simple Morphology of Rice Landraces in Tumbang Datu and Pongbembe

\begin{tabular}{|c|c|c|c|c|c|c|}
\hline Vernacular name & $\begin{array}{l}A^{\prime} d o(\text { awn) } \\
\text { color }\end{array}$ & $\begin{array}{c}\text { Awn } \\
\text { Length }\end{array}$ & $\begin{array}{l}\text { Barra' } \\
\text { (Rice) } \\
\text { color }\end{array}$ & $\begin{array}{c}\text { Rena' } \\
\text { (Grain) } \\
\text { color }\end{array}$ & $\begin{array}{l}\text { Shape } \\
\text { of grain }\end{array}$ & $\begin{array}{c}\text { Pulu' } \\
\text { (Glutin } \\
\text { ous) }\end{array}$ \\
\hline Pare Pulu' Kupa & Yellow & Long & $\begin{array}{l}\text { Thick } \\
\text { white }\end{array}$ & Yellow & Rounded & Yes \\
\hline Pare Bongi-Bongi & Yellow & Short & $\begin{array}{l}\text { Thick } \\
\text { white }\end{array}$ & $\begin{array}{l}\text { Blackish } \\
\text { yellow }\end{array}$ & Rounded & Yes \\
\hline Pare Pulu' Uban & Yellow & Short & $\begin{array}{l}\text { Thick } \\
\text { white }\end{array}$ & Yellow & $\begin{array}{c}\text { Slightly } \\
\text { oval }\end{array}$ & Yes \\
\hline Pare Baine & Black & Long & Pure white & Yellow & Rounded & No \\
\hline Pare Tongoran & Black & Short & Pure white & Yellow & Rounded & No \\
\hline Pare Lomben & Yellow & Long & Pure white & Yellow & Rounded & No \\
\hline Pare Boang Kamiri & Black & Long & Pure white & Yellow & Rounded & No \\
\hline Pare Pulu' Nakka & Black & Long & Pure white & Yellow & $\begin{array}{c}\text { Slightly } \\
\text { oval }\end{array}$ & Yes \\
\hline Pare Tanduk & Black & Long & Black & $\begin{array}{c}\text { Blackish } \\
\text { yellow }\end{array}$ & Oval & No \\
\hline Pare Palapa & Black & Long & $\begin{array}{l}\text { Thick } \\
\text { white }\end{array}$ & $\begin{array}{c}\text { Black } \\
\text { stripes }\end{array}$ & $\begin{array}{c}\text { Slightly } \\
\text { oval }\end{array}$ & Yes \\
\hline Pare Dewata & Red-brown & Long & Pure white & $\begin{array}{c}\text { Black } \\
\text { stripes }\end{array}$ & Rounded & No \\
\hline Pare Bintoen & Brown & Short & $\begin{array}{l}\text { Thick } \\
\text { white }\end{array}$ & Yellow & Rounded & Yes \\
\hline Pare Urang & Yellow & Long & $\begin{array}{l}\text { Thick } \\
\text { white }\end{array}$ & Yellow & $\begin{array}{c}\text { Slightly } \\
\text { oval }\end{array}$ & Yes \\
\hline Pare Kombong & Yellow & Long & $\begin{array}{l}\text { Thick } \\
\text { white }\end{array}$ & Yellow & Rounded & Yes \\
\hline Pare Kasalle & Red-brown & Long & Pure white & Yellow & Rounded & No \\
\hline Pare Ambo' & Black & Long & $\begin{array}{l}\text { Thick } \\
\text { black }\end{array}$ & $\begin{array}{l}\text { Blackish } \\
\text { yellow }\end{array}$ & Rounded & Yes \\
\hline
\end{tabular}

Copyright (C) 2020. Owned by Author(s), published by Society. This is an open-access article under the CC-BY-NC-SA license. 


\begin{tabular}{|c|c|c|c|c|c|c|}
\hline Vernacular name & $\begin{array}{c}\boldsymbol{A}^{\prime} \text { do (awn) } \\
\text { color }\end{array}$ & $\begin{array}{c}\text { Awn } \\
\text { Length }\end{array}$ & $\begin{array}{c}\text { Barra' } \\
\text { (Rice) } \\
\text { color }\end{array}$ & $\begin{array}{c}\text { Rena' } \\
\text { (Grain) } \\
\text { color }\end{array}$ & $\begin{array}{c}\text { Shape } \\
\text { of grain }\end{array}$ & $\begin{array}{c}\text { Pulu' } \\
\text { (Glutin } \\
\text { ous) }\end{array}$ \\
\hline Pare Lotong & Black & Short & Black & $\begin{array}{c}\text { Blackish } \\
\text { yellow }\end{array}$ & Rounded & No \\
\hline Pare $\mathbf{T o}^{\prime}\left(\mathbf{T u} \mathbf{u}^{\prime}\right)$ & Black & Short & Thick red & $\begin{array}{c}\text { Black } \\
\text { stripes }\end{array}$ & Rounded & Yes \\
\hline Pare Lea & Black & Medium & Thick red & $\begin{array}{c}\text { Reddish } \\
\text { yellow }\end{array}$ & Oval & Yes \\
\hline
\end{tabular}

Rice landrace policy supported by Indonesian Army program "TNI-AD Mendukung Ketahanan Pangan" (Army Supporting Food Security) program since 2014 at the local level, especially Village Guidance Officer or noncommissioned law enforcement officer (Babinsa) (Sebastian et al., 2018).

[Rice landrace is one of the main topics discussed in the Development Planning Consultation Forum]. Tana Toraja Regency runs the Crop Seasonal Program, so enable for harvesting twice a year. We support the efforts of the regency government to restore local wisdom by taking part in planting local rice. The challenge of growing local rice is that lacking labor since manual harvesting [using finger-bladed knife]. The farmers supply the seeds landrace varieties, while the regency government prepares tractors and any needed rice farming equipments (Interview, M1, Age 36, Tana Toraja).

\subsection{When: Planting and Harvesting Seasons}

Most farmers plant landraces once a year during the rainy season. As for the total rice planted area, it depends on how many seeds for the seedbed.

[When sowing and transplanting can be done for better rice yield?] "Allo melo (the best day)...patang $\left(a^{\prime} p a^{\prime}\right)$ sombo... [The full moon can be seen on the west during four nights in the row. The next day is the best day for planting]" (Interview, F1, Age 50, Pongbembe).

Ellis (2010) stated that farming based on the lunar cycle is part of biodynamic farming practices (organic farming is based on the moon and planets' circulation), affecting planting, and harvesting.

"I planted Pare Kombong three weeks ago. The agricultural cycle here is more complicated since the unequal rainfall distribution" (Interview, M2, Age 71, Tumbang Datu).

"Rice landrace seeds relocated from seedbed after two months, then harvested about five months later" (Interview, M3, Age 76, Tumbang Datu). 


\subsection{How: Various Methods of Processing Rice and Communicating Symbols of Rice 4.3.1. Cultivating rice landrace}

"Put the seeds in the sack...soak for two days, then partial drying for two days. After radicle emergence, sow seeds on the prepared seedbed. Transplant the seeds after three or four weeks. We could not cultivate the seeds that were already kept for two years. So, we must buy seeds or ask relatives or neighbors" (Interview, F2, Age 51, Tumbang Datu).

\subsubsection{Storing grains}

"[How do you store the seeds for the long term?] We are storing grains seeds separately in the granaries. There are some rituals for storing grains seeds" (Interview, M3, Age 76, Tumbang Datu).

"[How much grain is stored in the granary?] More than one hundred kutu' ((kutu' equals to 1,5 - 3 liters. It depends on vernacular terms in any region.) ...two hundred kutu' ...consume as much as needed...not for sale...I am a Parandangan [('The Points of Support') whose job description reads: 'to care for prosperity' (Nooy-Palm, 1979)]; the foundation-stone on which each of the pillars a house or rice bar are set; a committee of representatives Aluk To Dolo (Waterson, 2009)]" (Interview, F3, Age 67, Tumbang Datu).

\subsubsection{Removing husks}

"Removing husk and brans by a landrace milling machine. I give the owner liter of every 12 liters of milled rice as compensation (Interview, F2, Age 51, Tumbang Datu).

\subsubsection{Cooking rice}

"We use the manual rice milling process. First, dirurai [using issong dawa (rectangular-long wooden rice mortar) and bamboo as a pestle to pound and separate panicles and grains)]. Second, dita'pi (winnowing after dirurai, to clean rice brown husks). Third, ditangai (using issong te'dek [stone mortar and wooden pestle after dirurai]). Fourth, diseno (winnowing to separate brown husk and the rice). Fifth, disiri (winnowing to separate rena' (grains), banni' (groats) and rice. Sixth, dita'pi (the last winnowing) ... Cooking steps: dirurai - ditangai - dita'pi-put the water and rice into the clay pot, then cook over a wood-burning stove..." (Interview, F5, Age 13, Pongbembe).

\subsubsection{Consuming rice landrace: daily and rituals}

"Pare Boang Kamiri for daily consuming" (Interview, F4, Age 70, Pongbembe).

"[Consuming for rituals] ...stages of rice cultivation and rituals in Pongbembe...1) Massadang (cleaning the trenches) for a day before mangambo' (sowing seeds). Followed by ritual mangaluk paleppang, offering four different varieties of chickens (ma'manuk $\left.a^{\prime} p a^{\prime}\right)$ on the edge of the trench. These offerings for the gods: cooked rice 
and pakiki' (scraps of meat from all the different parts of whatever animal), except for the buku sanduk, or shoulder blade (Nooy-Palm, 1979). These offerings are set out on daun bere-bere (coral three leaves [Erythrina sp]), then put on kararo (coconut shell), set in tallung dandan (three rows), which represented three sources of power: Batara Tua, Batara Lolo, and Batara; 2) Ma'patama uai into palimbongan (flooding the rice fields) after cleaning the long trenches for two weeks; 3) Garaga panta'nakan (preparing seedbed): ma'bikkung (hoeing) and manglena' (leveling) the soil; 4) Manglullu' pare (using feet to separate rice seeds from stalks, for preparing the sowing seeds); 5) Mangambo' (sowing the seed on the seedbed); 6) Mangebu' (transplanting) after two months planting. Before plant all the seedlings, there is ritual ma'patoo' (plant the seedlings on four corners); 7) Makkalamo (weeding after a month of planting); 8) Matti'pa (weeding out the dikes); 9) Aluk bulung or ma'bulung (ma'bulung pare, an agrarian rite that is celebrated at the time when "green rice" begins to form its fruits [Salombe, 1975]) after 2-4 months planted. Sacrificed a pig at bamba (the village gate) and messun (making ketupat [steamed sticky rice that packed inside a diamond-shaped container of woven palm leaf pouch], then put into kabombongan (a display shelf; a woven-bamboo basket filled with offerings: bo'bo' cooked rice], pakiki' [porks], and egg, which hang down from the middle ao' kading [Phyllostachys pubescens], then plug into the ground at rice field]; 10) Messun (["to chase"]; There are three sacrifices which are thought to constitute not only the most important offerings the rice ritual but also the requirements aluk to mendeata (rites for the late are becoming life-spirits): a) ma'kamondong ("to clear"; the clearance of the grasses and parasitic plants which might impede the proper growth the crop), b) messun ("to chase"; the chasing away diseases which might affect the ripening rice), and c) mepare ("to harvest"; the proper harvesting rice plants as well as the successful transmission of their life-spirit to the yard of the house, where they are stacked and counted) [Tsintjilonis, 2000]); 11) Ma'palendu' pemulu (Prohibitions having to do with rice, home reparing, i.e., roof thatching) for a month. After 5-6 months; 12) Metaian (["waiting"]: Garaga lattang (building a simple shelter at rice field while doing mangramba dena' [bird-scaring], after six months planting). There are prohibitions on this step, i.e., fighting at the rice field and bringing meal or wood for lattang from the after-funeral ceremony); 13) Ma'karungingi': harvesting bua bungaran ([bua: fruit; bungaran: the beginning; the first [Blagden et al., 1897]) or bua pangrakan or indo' pare (["the mother of rice", that will be stored as seed for the next season. Prohibition buying and selling this rice [Yamashita, 1982]). This a day-feast held before harvesting all the crops. Mangrakan (roasting bua bungaran with its panicle then smoked or dried. Next step, pounding, cooking, then delivered for villagers. Usually, this rice is consumed with chicken meat or fish or bungkang (rice field crab, Parathelphusinae); 14) Mepare (harvesting). After mepare, cooked rice was put on the two plates, then kept on the pillow for \pm 20 minutes, as an offering for honoring the spirit of ancestors. The sheaves newly harvested rice set in a row (dilappo'; dipatuku; dimanuk-manuk). There is ritual ma'munu,' a chicken sacrificed and cooked rice in the night, then put beside lappo' (sheaves of harvested rice); 15) Ma'mawa or manglemba' (Carrying the harvested rice back to the house, the storing into the granaries), offering a chicken before opening granaries door for storing or taking the grains" (Interview, M4, Age 50, and M5, Age 56, Simbuang). 
During this interview, an individual's memory completed each other to recall the rice ritual steps in the past. Haft (2017) stated, leaving memory unexamined, and granting it the status of sacred or untouchable history, does memory itself a great injustice. Individual memory and collective memory are dynamic, which can be reduced or added by social interaction.
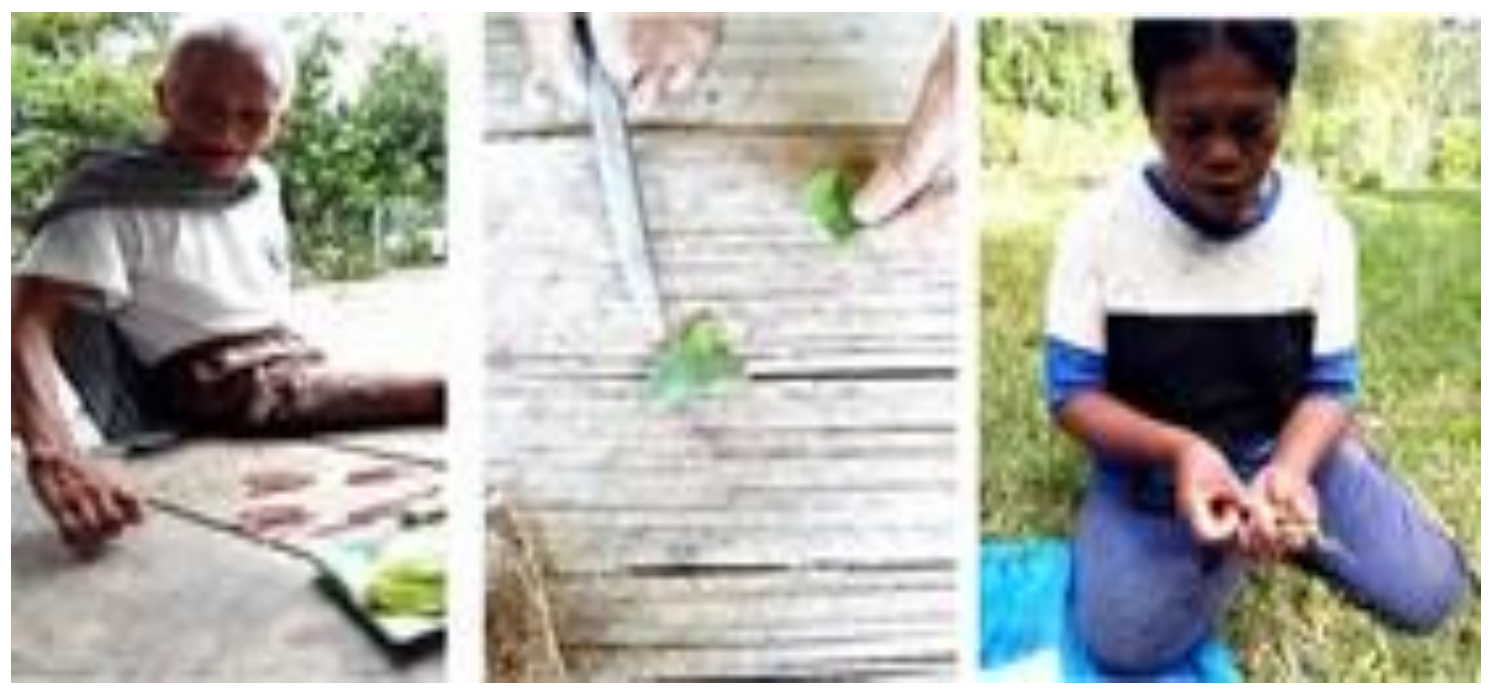

Figure 2. Various Mnemonic Devices

Cassava stalkers and various leaves are using for transmitting knowledge of rice landraces and rituals

Figure 2 shows that cultural practitioners (interviewees) use Basa Toraya (Toraja language) to transmit the shared experiences. The agriculture of Toraja encompasses individual innovations, individual experiences, memories, values, histories, songs, and dances. Virtues cognitive responses could be put in a simplified model of human-nature relationships (Krech et al., 1962), that belong to collective memories. According to MacIntyre, as cited in Van Houtan (2006), ethics require traditions constituted by practices that sustain communities over generations through scientific arguments and rituals.

\subsubsection{Doing arts and communicating symbols and values of rice}

Teenagers as a symbol of continuity and Toraja's future. Teenagers in this article shared cultural knowledge to navigate a cultural environment with cultural competence.

"[Do you know the motifs carving on the granary?] Yes! Pa'tedong, Pa'bare allo, Pa'pollo' gayang, Pa'kapu' baka, Pa'daun bolu... [Do you practice some arts-related to rice?] Yes, I do Pa'gellu' (Toraja dance, performed in thanksgiving or excitement ceremonies) [all the interviewees replied] and folk song To Mepare (the reapers, manually)" (Interview, FGD, F6, F7, F8, M6, Age 13-17, Tumbang Datu).

Since early childhood, those students actively engaged in rituals or ceremonies as part of the learning process symbolic dimension. “...The learning of language has been integral to the learning of culture; the ritual is a cultural language through which the child learns to symbolize the world and learns how to order life within that world or meanings (Bell \& Valentine, 1997, as cited in Smith, 2013). As Smith (2013) puts, “...The language of ritual may remain unspoken but not forgotten and at every opportunity is brought out and spoken with intensity and enjoyment." Passura' (motifs) on wooden-carving granaries and banua tongkonan (banua: house; tongkonan: kinship group; also called banua pa'rapuan) are cultural artefacts from the ancestors. 
Houses are the sites for major ritual performances. Some motifs represent the relationship between humans, plants, and livestock (aluk tallu lolona): 1) Pa'barre allo and manuk (sunburst and cock); 2) Pa'tedong (buffalo head); 3) Pa'lolo tabang (cordyline shoots, Cordyline fruticosa); 4) Pa'barana' (banyan leaf, Ficus benjamina); 5) Pa'daun bolu (betel leaf, Piper betle); 6) Pa'bulu londong (cocks' feathers); 7) Pa'tangke lumu' (waterweed); 8) Pa'tedong tumuru (wallowing buffalo); 9) Pa'pollo' gayang (kris hilts); 10) Pa'kalumpini (swallows, Collocalia vestita); and 11) Pa'barra' (grains) (Waterson, 1988). Acts of remembering within a conversation supply a context in which conversing individuals can influence each other's memory (Hirst \& Echterhoff, 2012). The later collective memories, in turn, can be passed down from one generation to the next and can eventually be incorporated into the cultural artifacts produced by the community.

\subsubsection{Selling seeds of rice landraces}

"The seeds not for selling, if someone asking for less than ten kutu.' Ten kutu' for Indonesian Rupiah (IDR) 30.000... a liter (L) Pare Kombong for IDR 20.000, Pare Barri IDR 10.000, Pulu' Lea (red glutinous rice) and Pulu' Busa (white glutinous rice) for IDR 20.000. Sometimes Pulu'Busa mixed with black rice, a liter IDR 20.000. These varieties are expensive for its importance in aluk (ritual needs), especially Pulu' Lea, Pulu' Busa, and pare lotong (black rice) ... We need 20 kutu' Pulu' Lea and Pulu' Busa, pare lotong ten kutu'" (Interview, M2, Age 71, Tumbang Datu).

[Which variety for selling?] Pare Tanduk and pare Lomben...each IDR 15,000/L. [Where?] Le'ke' Market or Makale. Sometimes the buyers order for 10L... (Interview, Maria, Age 50, Pongbembe).

"Pare Dewata IDR 10,000/L, Pare Tanduk for diabetic diet, IDR 25,000/L... [If you want to plant but do not have any seed of rice landraces?] You can ask or exchange seeds. [How much?] As needed. [Any seed landrace for selling?] No! The seeds that will be planted are for sale. If you want to return it, then wait for the next harvest" (Interview, F9, Age 50, Simbuang).

"...Seeds must be stored. But seeds that have been stored for two years cannot be cultivated.... Usually, I bought seeds from a neighbor or anyone who still has seeds. Usually, I bought Pulu' Lea, Pulu' Busa, Pulu' Lotong, Pare Kombong each IDR 50.000 for 20 kutu'" (Interview, F2, Age 51, Tumbang Datu).

\subsection{Why Cultivating Rice Landrace}

\subsubsection{Cultural heritage and collective identity}

"[Why do rice landraces important to cultivate? Why do you keep growing landraces?] ...Our parents never cultivated another variety ...The types of soil here are not suitable for improved varieties" (Interview, F1, Age 50, Pongbembe).

"These landraces are important for the spiritual of Torajans due to conduct rituals...The rituals cannot be carried out without these rice" (Interview, M2, Age 71, Tumbang Datu). 


\subsubsection{Exchanging and circulating seeds}

[Important for circulating and exchanging seeds] ...One time we will need a certain variety, someone else will give it... (Interview, F1, Age 51, Pongbembe).

Biodiversity depends on the degree of intimacy and socialization forms that humankind supports (Caillon \& Degeorges, 2007). Even though Aluk pare is rooted in Aluk To Dolo, recently, Catholic or Protestant adherents who involved in conserving rice landrace, perceive themselves as the generations taking responsibility for rice landrace as cultural heritage and collective identity.

\subsection{Where: House (clan and household) and rice field}

The agricultural rituals are taken place in some sites, as mentioned in "Consuming rice landraces for rituals" in Pongbembe. Nevertheless, there are places for rituals in Tumbang Datu.

[This is] a ritual site, a small rock of lime, where people come (langngan buntu) to bring offerings called manta'da (asking) after harvesting (Interview, M11, Age 37, Tumbang Datu).

"Rice fields owned by adherents Aluk To Dolo are called uma tae'pa na sarani (the owner is not yet Christian). It is forbidden to cultivate pare lotong (black rice) here. You can find a place for rituals in this rice field where...there is a stack of stones to put offerings in doing ma'pesung (bringing an offering on pieces banana-leaf). Every year a stone is erected, the sacred one. A pig and cooked glutinous rice are offered. Forbidden to touch the stones. I offered a chicken for every ten rice fields. Any chicken, except buri' (a spotted cock), because the deities are unpropitious. Pig sacrificing especially for this Limbong Kalua' (a name for the special rice field)" (Interview, F3, Age 67, Tumbang Datu).

"...I did not find rice field conversion here due to its socio-cultural values...special rice field, uma tae' pa na sarani, only cultivating for Pare Kasalle" (Interview, F10, Age 45, Tombing Datu).

\subsection{Who: Various social categories}

As cited in interviews in this article (Table 1), there are various gender, ages, and roles in transmitting knowledge and memories in doing agriculture rituals and landraces.

\subsection{Revisiting Conservation of Rice Landrace}

\subsubsection{Tradition-based conservation: non-standard method of conservation through the empirical way}

A study on landrace showed that taro landrace plays a role in feeding populations and contributes to defining the groups' identity cultivating it (Caillon \& Lanouguère-Bruneau, 2004). Agriculture tradition-based has been elaborated on "How: cultivating, storing, cleaning husks, cooking, and consuming (daily and rituals)" in this article. Farmers are proud to implement tradition-based conservation landrace. 


\title{
4.7.2. Current scientific technology-based conservation: standard method by agricultural agency and agricultural extension
}

\begin{abstract}
"[Type of soil?] Clay loam...Planted area around 46 ha...Topography: mostly slopes. Rainfall: high. Moisture: slightly moist. Temperature: medium. Planting Conditions: slope. Cropping pattern: random 80\%, Jajar Legowo 20\% (for superior varieties). Seed sources: exchanging seed among individuals, locally. Ploughing method: hoeing manually and using tractors. Direct Seeding System (Tanam Benih Langsung: Tabela) around $40 \%$. A nursery randomly for a hole, usually a hole fill with ten grains...using organic fertilizer. Farmers were taking one crop a year for keeping soil fertility...Fertilization once in seeding.... Pests of rice: most mice, sparrows, also there are many wild buffalo. Plant Disturbing Organisms (Organisme Pengganggu Tanaman): sometimes blast...We must manage the plant space...Plant disease: neck blast rot...Preventing these problems by managing the water and spraying insecticides. Harvesting activity: 3.5-4 tons per ha..." (Interview, M7, Age 36, Simbuang).
\end{abstract}

Centre for Plant Variety Protection and Agricultural Licensing (PVPAL), Ministry of Agriculture, released local varieties rice certification on 18 November 2013 to North Toraja Regency: 1) Pare Ambo', 2) Pare Lea; 3) Pare Kombong, and 4) Pare Lallodo. The interviews showed that some farmers in Tumbang Datu are cultivating Pare Kombong and Pare Lallodo, while the varieties in Pongbembe are waiting for certification. Scholars in Toraja studies have neglected the importance of contributions to various gender, age, and occupations interviewees who conserve landraces by everyday behaviors. Such behaviors have remained mostly invisible to scholars due in large part to payment for living and funeral ceremonies (de Jong, 2013; Adams, 2020), ecotourism (Avenzora, 2003), also, politics and identity studies (Klenke, 2013). Rice landrace conservation in Tumbang Datu and Pongbembe is an everyday foodways of community members. These repeated observations and interactions with the ecosystem landrace varieties or climate change would increase individuals' knowledge and awareness of biodiversity (Cosquer et al., 2012). Meanwhile, self-learning on rice landrace contributed to increasing individual motivations to take part in conservation.

There are 'different points' and 'localized process in social interpretation' on Blumer's network. As Blumer stated on the network in symbolic interactionism, individuals in conservation rice landrace purposively selected in this study to draw the various background of interviewees as different points. Today, interviewees define the situation and act as manifested in adapting earlier or inherited rice landmarks' foodways. Here, meanings of rice landrace are formed, sustained, weakened, strengthened, or transformed. Symbols and meanings of rice are expressed in how, when, and which important varieties to cultivate; or the symbols of motifs on wooden-carving granaries. The best practice of this study shows anyone could engage in the conservation of rice landrace. Moreover, the localized process in social interpretation' needs to address memory as the basis of conservation, which could be implemented from an early age.

This article asserts sociology contributions to exploring the symbolic interaction approach to reveal collective memory, foodways, meanings, and rice symbol in the past. The transdisciplinary approach of sociology, ethnobotany, and communication studies highlights social practices in which rice landrace as the plant is used, in different use and knowledge and collective memory on foodways. Meanwhile, collective memory is a living concept that 
symbolizes rice in the past, reinterpreted and renewed by communicating, adapting, and practicing in this present moment.

\section{Conclusion}

The performance of the agricultural system in Tana Toraja is effectively supporting rice landraces conservation. As hypothesized, this study proved that the ecosystem of conservation is applicable as a framework for engaging adherents of Aluk To Dolo in rice rituals. Meanwhile, some parts of the rice ritual have been adapted to current conditions because some Aluk To Dolo adherents have converted.

Blumer's social structures as networks of interdependence among communities' members are supporting conservation rice landrace. As he stated, 'localized process social interpretation', conservation rooted in collective memory, is reflected in everyday foodways. Here, studies on these social structures could extend for issues, i.e., endangered vernacular language, cultural dynamics, and collective identity in networks.

The results showed that collective memories and foodways create ways that would benefit landrace conservation performance the most. Meanwhile, tradition-based conservation and current scientific-technology-based conservation are employing to preserve collective memory and foodways. This study suggests documenting, monitoring, and controlling genetic diversity at community levels. Furthermore, the history of varieties distribution in Tumbang Datu and Pongbembe needs morphological traits analysis and cultural or use significance in detail for distinguishing landrace diversity.

\section{Limitations}

The evidence from this study points to the idea that the collaborations and networks have improved rice landraces cultivation in Tana Toraja. In the future, this article suggests completed landrace diversity in the agriculture cycle and rituals. Furthermore, the transdisciplinary approach has showed that a combination of non-standard methods and standard methods are the strategies that would benefit the performance of rice landrace conservation the most. Conservation practices sustained communities over generations by scientific arguments and rituals. Here, conservation requires expression in social traditions' language if they are to be authentic and realized. In this context, strategies are manipulating for strengthening collective identity and the networks themselves.

\section{Acknowledgment}

This study was made possible by a grant from Beasiswa Unggulan Dosen Indonesia Dalam Negeri (BUDI-DN) through the Ministry of Research, Technology, and Higher Education of the Republic of Indonesia (KEMRISTEKDIKTI), together with the Indonesia Endowment Fund for Education (LPDP). We thank all interviewees who already cited in this article. We also thank Prof T.R. Andi Lolo, Ph.D., Muhammad Fuad Anshori, Lukáš Pawera, Agustina Y.S. Arobaya, Dewangga Selangga, Leonardus Agung Sri Baskara, Rukka Sombolinggi, Syafitri Hidayati, Arnold Souisa, and anonymous reviewers for supplied useful comments on the earlier draft on this paper.

\section{Declaration of Conflicting Interests}

The authors have declared no potential conflicts of interest concerning the study, authorship, and/or publication of this article. 


\section{References}

Adams, K. M. (2020). What western tourism concepts obscure: intersections of migration and tourism in Indonesia. Tourism Geographies, 1-26. https:/ / doi.org/10.1080/14616688.2020.1765010

Ajwang'Ondiek, R., Kitaka, N., \& Oduor, S. O. (2016). Assessment of provisioning and cultural ecosystem services in natural wetlands and rice fields in Kano floodplain, Kenya. Ecosystem Services, 21, 166-173. https:/ / doi.org/10.1016/j.ecoser.2016.08.008

Aldiabat, K. M., \& Navenec, L. (2011). Philosophical roots of classical grounded theory: Its foundations in symbolic interactionism. Qualitative Report, 16(4), 1063-1080. Retrieved May 11, 2019, from http:/ / www.nova.edu/ssss/QR/QR16-4/aldiabat.pdf

Álvarez-Romero, J. G., Mills, M., Adams, V. M., Gurney, G. G., Pressey, R. L., Weeks, R., ... Storlie, C. J. (2018). Research advances and gaps in marine planning: towards a global database in systematic conservation planning. Biological Conservation, 227, 369-382. https:/ / doi.org/10.1016/j.biocon.2018.06.027

Appelrouth, S., \& Edles, L. D. (2007). Sociological theory in the contemporary era: Text and readings. Thousand Oaks, California: Sage.

Arangote, E. (2018). Implication to Environmental Education of Indigenous Knowledge and the Ecosystem of Upland Farmers in Aklan, Philippines. IOP Conference Series: Earth and Environmental Science, 012022. Barcelona, Spain: IOP Publishing. https://doi.org/10.1088/1755-1315/167/1/012022

Auersbach, B. (2018). The House, The Rice and The Buffalo: Cosmological Perceptions in the indigenous Architecture of Southeast Asia. SPAFA Journal, 2, 1-8. https:/ / doi.org/10.26721/spafajournal.v2i0.586

Avenzora, R. (2003). Integrated and ecological planning of sustainable tourism development in a rural area in Indonesia. Dissertation. Georg-August University, Göttingen. Retrieved October 27, 2019, from http://ediss.uni-goettingen.de/bitstream/handle/11858/00-1735-0000-0006B15A-7/ avenzora.pdf?sequence $=1$

Badan Pusat Statistik (BPS) Kabupaten Tana Toraja (2018a, August). Simbuang Dalam Angka 2018 (Simbuang in Figures 2018). Retrieved October 25, 2019, from https:/ / tatorkab.bps.go.id/publication/2018/09/26/3d5ecb4fce262e64dd683ab0/kecam atan-simbuang-dalam-angka-2018.html

BPS Kabupaten Tana Toraja (2018b, August). Sangalla Utara Dalam Angka 2018 (Sangalla Utara in Figures 2018). Retrieved October 25, 2019, from https:/ / tatorkab.bps.go.id/publication/2018/09/26/5ed7d16141549229bf8504ce/kecam atan-sangalla-utara-dalam-angka-2018.html

Budiman, M. (2008). Nejoýznamnější toradžské rituály a jejich dnešní podoba (The most important Toraja rituals and their current form). Disertační práce. Univerzita Karlova, Prague. Retrieved October 27, 2019, from https:/ / core.ac.uk/download/pdf/144303921.pdf.

Bennett, N. J., Roth, R., Klain, S. C., Chan, K. M. A., Clark, D. A., Cullman, G., ... Veríssimo, D. (2016). Mainstreaming the social sciences in conservation. Conservation Biology, 31(1), 5666. https:/ / doi.org/10.1111/cobi.12788

Blagden, C. O., Merewether, E. M., \& Ja'far, M. (1897). An account of the cultivation of rice in Malacca. Journal of the Straits Branch of the Royal Asiatic Society, 30(3), 285-304.

Brush, S. B. (1991). A Farmer-based approach to conserving crop germplasm. Economic Botany, 45(2), 153-165. https:/ / doi.org/10.1007/bf02862044

Caillon, S., \& Lanouguère-Bruneau, V. (2004). Taro diversity in a village of Vanua Lava Island (Vanuatu): Where, what, who, how and why? In L. Guarino, M. B. Taylor, \& T. Osborn

Copyright (C 2020. Owned by Author(s), published by Society. This is an open-access article under the CC-BY-NC-SA license. 
(eds.), Third Taro Symposium, 21-23 May 2003, Nadi, Fiji Islands: Proceedings of An International Scientific Meeting (pp. 58-63). Fiji: International Scientific Meeting Committee. Retrieved Apr 27, 2018, from https:/ / agritrop.cirad.fr/597116/

Caillon, S., \& Degeorges, P. (2007). Biodiversity: Negotiating the border between nature and culture. Biodiversity Conservation, 16(10), 2019-2931. https:/ / doi.org/10.1007/s10531-0079149-7

Charnley, S., Carothers, C., Satterfield, T., Levine, A., Poe, M. R., Norman, K., ... St. Martin, K. (2017). Evaluating the best available social science for natural resource management $\begin{array}{lllll}\text { decision-making. Environmental Science } \mathcal{E} \quad \text { Policy, } & \text { 73, 88. }\end{array}$ https:// doi.org/10.1016/j.envsci.2017.04.002

Coleman, J. L., Ascher, J. S., Bickford, D., Buchori, D., Cabanban, A., Chisholm, R. A., ... Carrasco, L. R. (2019). Top 100 research questions for biodiversity conservation in Southeast Asia. Biological Conservation, 234, 211-220. https:// doi.org/10.1016/j.biocon.2019.03.028

Coman, A., Momennejad, I., Drach, R. D., \& Geana, A. (2016). Mnemonic convergence in social networks: The emergent properties of cognition at a collective level. In P. N. A. Sciences (Ed.), Proceedings of the National Academy of Sciences (pp. 8171-8176). Washington, DC: National Academy of Sciences. https:/ / doi.org/10.1073/pnas.1525569113

Cosquer, A., Raymond, R., \& Prevot-Julliard, A. C. (2012). Observations of Everyday Biodiversity: a New Perspective for Conservation? Ecology and Society, 17(4), 2. https:/ / doi.org/10.5751/es-04955-170402

Counihan, C. M. (1999). The anthropology of food and body: Gender, meaning and power. New York \& London: Routledge.

Crystal, E. (1989). Myth, symbol and function of the Toraja House. Traditional Dwellings and Settlements Review, 1(1), 7-17. https://www.jstor.org/stable/23565486

DiMaggio, P. (1997). Culture and cognition. Annual Review of Sociology, 23(2), 263-287. https://doi.org/10.1146/annurev.soc.23.1.263

Ellis, J. (2010). Is there a role in UK Agriculture for Farming by the Cycles of the Moon?. A Nuffield Farming Scholarships Report. Retrieved October 27, 2019, from https:// nuffieldinternational.org/live/Report/UK/2009/julian-ellis

Edwin de Jong. (2013). Making a Living between Crises and Ceremonies in Tana Toraja: The Practice of everyday Life of a South Sulawesi highland Community. Leiden/Boston: Brill.

Fine, G. A., \& Kleinman, S. (1983). Network and Meaning: An Interactionist Approach to Structure. Symbolic Interaction, 6(1), 97-110. https:/ / doi.org/10.1525/ si.1983.6.1.97

Fine, G. A., \& Beim, A. (2007). Introduction: Interactionist Approaches to Collective Memory. Symbolic Interaction, 30(1), 1-5. https:/ / doi.org/10.1525/ si.2007.30.1.1

Glover, D., \& Stone, G. D. (2017). Heirloom rice in Ifugao: an 'anti-commodity' in the process of commodification. The Journal of Peasant Studies, 45(4), 776-804. https:/ / doi.org/10.1080/03066150.2017.1284062

Gopi, G., \& Manjula, M. (2018). Speciality Rice Biodiversity of Kerala: Need for Incentivising Conservation in the Era of Changing Climate. Current Science, 114(05), 997. https:/ / doi.org/10.18520/cs/v114/i05/997-1006

Haft, H. (2017). Telling memories. Retrieved October 25, 2019, from https:/ / aeon.co/essays/what-the-oral-histories-of-russian-jews-reveal-about-memory

Hirst, W. (2020). Is Collective Forgetting Virtuous? Journal of Applied Research in Memory and Cognition, 9(1), 37-41. https:/ / doi.org/10.1016/j.jarmac.2019.12.007

Copyright (C 2020. Owned by Author(s), published by Society. This is an open-access article under the CC-BY-NC-SA license. 
Hirst, W., \& Echterhoff, G. (2012). Remembering in Conversations: The Social Sharing and Reshaping of Memories. Annual Review of Psychology, 63(1), 55-79. https:// doi.org/10.1146/annurev-psych-120710-100340

Hongsong, W., \& Yunyue, W. (2017). Factors Influencing Indigenous Rice Protection in the Yuanyang Terraced Rice Fields of China. Journal of Resources and Ecology, 8(3), 287-295. https:// doi.org/10.5814/j.issn.1674-764x.2017.03.009

Iskandar, J., \& Ellen, R. (1999). In situ conservation of rice landraces among the Baduy of West Java. Journal of Ethnobiology, 19(1), 97-126. Retrieved October 16, 2019, from https://ethnobiology.org/sites/default/files/pdfs/JoE/19-1/Iskandar.pdf

Juhriah, M. A., Tambaru, E., \& Sajak, A. (2014). Karakterisasi Morfologi Malai Padi Lokal Asal Kabupaten Tana Toraja Utara, Sulawesi Selatan. Sainsmat: Jurnal Ilmiah Ilmu Pengetahuan Alam, 2(1), 22-31. https://ojs.unm.ac.id/sainsmat/article/view/749

Keightley, E., \& Pickering, M. (2012). The mnemonic imagination. Remembering as creative practice. New York, United States: Palgrave Macmilllan.

Kendall, L. (2010). 6. The Changsŭng Defanged: The Curious Recent History of a Korean Cultural Symbol. In L. Kendall (Ed.), Consuming Korean Tradition in Early and Late Modernity (pp. 127-148). Honolulu: University of Hawaii Press. https:// doi.org/10.1515/9780824860813-008

Klenke, K. (2013). Whose adat is it? Adat, Indigeneity and Social Stratification in Toraja. (pp. 149165). In Hauser-Schäublin, B. (Ed.). Adat and Indigeneity in Indonesia. Culture and Entitlements between Heteronomy and Self-Ascription. Göttingen Studies in Cultural Property, Volume 7. Universitätsverlag Göttingen. Retrieved Apr 25, 2020, from https://library.oapen.org/bitstream/handle/20.500.12657/32549/610301.pdf?sequence= 1 \#page $=157$

Koubi, J. (1975). La première fête funéraire chez les Toraja Sa'dan. Archipel, 10(1), 105-119. https:// doi.org/10.3406/arch.1975.1243

Krech, D., Crutchfield, R. S., \& Ballachey E. L. (1962). Individual in society: A textbook of Social Psychology. New York \& San Francisco: McGraw-Hill.

Kruyt, D. A. C. (1938). Het Schommelen in de Indische Archipel. Bijdragen Tot de Taal-, Land- En Volkenkunde, 97(1), 363-424. https:// doi.org/10.1163/22134379-90001341

Kumbhar, S. D., Kulwal, P. L., Patil, J. V., Sarawate, C. D., Gaikwad, A. P., \& Jadhav, A. S. (2015). Genetic Diversity and Population Structure in Landraces and Improved Rice Varieties from India. Rice Science, 22(3), 99-107. https:// doi.org/10.1016/j.rsci.2015.05.013

Laing, G. K. (2010). An Empirical Test of Mnemonic Devices to Improve Learning in Elementary Accounting. Journal of Education for Business, 85(6), 349-358. https:// doi.org/10.1080/08832321003604946

Macionis, J. J. (2018). Sociology (16th ed.). Harlow, UK: Pearson.

Molina, J., Sikora, M., Garud, N., Flowers, J. M., Rubinstein, S., Reynolds, A., ... Purugganan, M. D. (2011). Molecular evidence for a single evolutionary origin of domesticated rice. Proceedings of the National Academy of Sciences, 8351-8356. Barcelona, Spain: Proceedings of the National Academy of Sciences. https:// doi.org/10.1073/pnas.1104686108

Murphy, K. M. (2017). A quiet harvest: linkage between ritual, seed selection and the historical use of the finger-bladed knife as a traditional plant breeding tool in Ifugao, Philippines. Journal of Ethnobiology and Ethnomedicine, 13(1), 1-12. https://doi.org/10.1186/s13002016-0124-9 
Ngelow, Z. J. (2004). Traditional culture, christianity and globalization in Indonesia: The case of Torajan Christians. Inter-Religio, 45 (2), 3-11. Retrieved July 15, 2020, from https:/ / nirc.nanzan-u.ac.jp/nfile/3455

Nooy-Palm, H. (1979). The Sa'dan-Toraja: A Study of Their Social Life and Religion. I: Organization, Symbol and Beliefs. The Hague: Brill.

Oguamanam, C. (2004). Localizing Intellectual Property in the Globalization Epoch: The Integration of Indigenous Knowledge. Indiana Journal of Global Legal Studies, 11(2), 135-169. https://doi.org/10.2979/gls.2004.11.2.135

Ohmer, M. L., Meadowcroft, P., Freed, K., \& Lewis, E. (2009). Community Gardening and Community Development: Individual, Social and Community Benefits of a Community Conservation Program. Journal of Community Practice, 17(4), 377-399. https:/ / doi.org/10.1080/10705420903299961

Panicker, A., Basu, K., \& Chung, C.-F. (2020). Changing Roles and Contexts: Symbolic Interactionism in the Sharing of Food and Eating Practices between Remote, Intergenerational Family Members. Proceedings of the ACM on Human-Computer Interaction, 4(CSCW1), 1-19. https:/ / doi.org/10.1145/3392848

Plummer, K. (2000). Symbolic Interactionism in the Twentieth Century. In B.S, Turner (Ed.) The Blackwell Companion to Social Theory (2nd ed., pp. 193-222). Malden, MA: Blackwell Publishers.

Pohl, C. (2011). What is progress in transdisciplinary research? Futures, 43(6), 618-626. https:/ / doi.org/10.1016/j.futures.2011.03.001

Poudel, D., Sthapit, B., \& Shrestha, P. (2015). An Analysis of Social Seed Network and Its Contribution to On-Farm Conservation of Crop Genetic Diversity in Nepal. International Journal of Biodiversity, 2015, 1-13. https:/ / doi.org/10.1155/2015/312621

Ritzer, G. (2011). Sociological Theory. New York, United States: McGraw-Hill.

Ritchey, T. (2011). General Morphological Analysis (GMA). In: Bad Issues - Social Messages. Risk, Governance and Society, 17. Heidelberg: Springer. https://doi.org/10.1007/978-3-64219653-9_2

Salombe, C. (1975). Une version orale du mythe de Sawérigading recueillie à Kandora, Méngkéndek, Pays Toraja. Archipel, 10(1), 269-287. https:// doi.org/10.3406/arch.1975.1253

Salvini, A. (2010). Symbolic Interactionism and Social Network Analysis: An Uncertain Encounter. Symbolic Interaction, 33(3), 364-388. https:/ / doi.org/10.1525/ si.2010.33.3.364

Schultes, R. E. (1994). The Importance of Ethnobotany in Environmental Conservation. American Journal of Economics and Sociology, 53(2), 202-206. https://doi.org/10.1111/j.15367150.1994.tb02586.x

Sebastian, L. C., Syailendra, E. A., \& Marzuki, K. I. (2018). Civil-Military Relations in Indonesia after the Reform Period. Asia Policy, 25(3), 49-78. https://doi.org/10.1353/asp.2018.0041

Smith, I. C. (2013). Foodways, families, and festivities: Ethnobiology and cultural conservation in a rural Missouri community. Theses and Dissertations. Retrieved Jan 21, 2020, from http:/ / scholarworks.uark.edu/etd/725

Soini, K., Diaz, C., Gandini, G., de Haas, Y., Lilja, T., Martin-Collado, D., ... Hiemstra, S. J. (2012). Developing a typology for local cattle breed farmers in Europe. Journal of Animal Breeding and Genetics, no. https:/ / doi.org/10.1111/j.1439-0388.2012.01009.x

Strang, V. (2007). Integrating the social and natural sciences in environmental research: a discussion paper. Environment, Development and Sustainability, 11(1), 1-18. https:/ / doi.org/10.1007/s10668-007-9095-2

Copyright (C) 2020. Owned by Author(s), published by Society. This is an open-access article under the CC-BY-NC-SA license. 
Tilliger, B., Rodríguez-Labajos, B., Bustamante, J., \& Settele, J. (2015). Disentangling Values in the Interrelations between Cultural Ecosystem Services and Landscape Conservation - A Case Study of the Ifugao Rice Terraces in the Philippines. Land, 4(3), 888-913. https:// doi.org/10.3390/land4030888

Tsintjilonis, D. (2000). A Head for the Dead: Sacred Violence in Tana Toraja. Archipel, 59(1), 2750. https:/ / doi.org/10.3406/arch.2000.3553

van der Kroef, J. M. (1952). Rice Legends of Indonesia. The Journal of American Folklore, 65(255), 49. https:/ / doi.org/10.2307/536286

van Driem, G. (2012). The ethnolinguistic identity of the domesticators of Asian rice. Comptes Rendus Palevol, 11(2-3), 117-132. https:/ / doi.org/10.1016/j.crpv.2011.07.004

van Houtan, K. S. (2006). Conservation as virtue: A scientific and social process for conservation ethics. Conservation Biology, 20(5), 1367-1372. https://doi.org/10.1111/j.15231739.2006.00447.x

Veen, H. V. D. (1979). Overleveringen en zangen der Zuid-Toradja's. VKI 85. The Hague, NL: Martinus Nijhoff. doi: 10.26530/OAPEN_613345. Retrieved Feb 15, 2019, from https:/ / library.oapen.org/handle/20.500.12657/32265

Volkman, T. A. (1984). great performances: Toraja cultural identity in the 1970s. American Ethnologist, 11(1), 152-169. https:/ / doi.org/10.1525/ae.1984.11.1.02a00090

Wang, Y., Wang, Y., Sun, X., Caiji, Z., Yang, J., Cui, D., ... Han, L. (2016). Influence of ethnic traditional cultures on genetic diversity of rice landraces under on-farm conservation in southwest China. Journal of Ethnobiology and Ethnomedicine, 12(1), 1-14. https:/ / doi.org/10.1186/s13002-016-0120-0

Waterson, R. (1988). The house and the world. The symbolism of Sa'dan Toraja house carvings. RES, 15, 35-60. https:/ / doi.org/10.1086/RESv15n1ms20166785

Waterson, R. (2009). Paths and Rivers. Sa'dan Toraja Society in Transformation. Leiden (NL): KITLV Press.

Yamashiro, J. K., \& Hirst, W. (2014). Mnemonic convergence in a social network: Collective memory and extended influence. Journal of Applied Research in Memory and Cognition, 3(4), 272-279. https:/ / doi.org/10.1016/j.jarmac.2014.08.001

Yamashita, S. (1982). 水田ミナンガ. サダン.トラジャのー 枚の水田をめる社会人類学 的覚 書 き (Uma Minanga. An anthropological note of Sa'dan Toraja Rice Cultivation. Southeast Asian Studies, 20(3), 373-392. https://doi.org/10.20495/tak.20.3_373. Retrieved Feb 16, 2019, from https://www.jstage.jst.go.jp/article/tak/20/3/20_KJ00000133860/_pdf/char/ja

Zerner, C. (1985). The golden waterworks: Toraja rituals of the wet-rice landscape. Arnoldia, 45(3), 2-12. Retrieved Oct 20, 2019, from https://www.jstor.org/stable/ 42954227

\section{About the Authors}

1. Ikma Citra Ranteallo earned a Master of Arts in Sociology from Universitas Gadjah Mada, Indonesia. She is lecturer at Department of Sociology, Faculty of Social and Political Sciences, Universitas Udayana, Indonesia. Currently, she is doctoral student at Department of Communication Science and Community Development, Faculty of Human Ecology, Institut Pertanian Bogor, Indonesia.

E-Mail: ikma_citra@unud.ac.id 
2. Meredian Alam holds a Doctoral of Philosophy in Sociology and Anthropology from University of Newcastle, Australia. He is assistant professor at Department of Sociology and Anthropology, Faculty of Arts and Social Science, Universiti Brunei Darussalam.

E-Mail: meredian.alam@ubd.edu.bn

3. Azwar Hadi Nasution obtained Magister of Soil Technology and Environment, Institut Pertanian Bogor. He was former of Seed Bank Collection Division at Association of Indonesian Seed Bank and Farmers Agricultural Technology (AB2TI), Bogor, Indonesia.

4. Lala M. Kolopaking earned a doctoral degree from Universiti Sains Malaysia. He is lecturer at Department of Communication Science and Community Development, Faculty of Human Ecology, Institut Pertanian Bogor, Indonesia.

E-Mail: lalako@apps.ipb.ac.id

5. Djuara P. Lubis earned his PhD in Development Communication from University of the Philippines Los Baños, Philippines. He is lecturer at Department of Communication Science and Community Development, Faculty of Human Ecology, Institut Pertanian Bogor, Indonesia.

E-Mail: djuaralubis@gmail.com

6. Ervizal A. M. Zuhud obtained his doctoral degree from Institut Pertanian Bogor, Indonesia. He is a professor at Department of Forest Resources Conservation and Ecotourism, Faculty of Forestry, Institut Pertanian Bogor, Indonesia.

E-Mail: eamzuhud@apps.ipb.ac.id

7. Imanuella R. Andilolo holds a Master of Science from University of Tilburg, Netherlands. She is lecturer at Department of Management, Faculty of Economics and Business, Faculty of Economics and Business, Universitas Mataram, Indonesia.

E-Mail: imanuelita@gmail.com 